\title{
Pelatihan Soal Matematika Berbasis Literasi Numerasi pada Siswa SMA IT Fitrah Insani
}

\section{Numeration Literacy-Based Mathematics Training in SMA IT Fitrah Insani Students}

\author{
Nicky Dwi Puspaningtyas ${ }^{1}$, Marchamah Ulfa ${ }^{2}$ \\ *Universitas Teknokrat Indonesia,nicky@teknokrat.ac.id
}

\begin{abstract}
Abstrak
Pengabdian kepada masyarakat ini bertujuan untuk: 1) memberikan pengetahuan bagi siswa terkait soal-soal berbasis literasi numerasi matematika, 2) melatih keterampilan siswa dalam menyelesaikan soal berbasis literasi numerasi matematika. Metode yang digunakan dengan memberikan pelatihan dan pendampingan siswa dalam menyelesaikan soal berbasis literasi numerasi matematika. Pelatihan dilakukan secara virtual dengan aplikasi google classroom dan zoom. Data diperoleh dari hasil pre-test dan post-test kemudian diuji perbedaan dua rata-ratanya dengan menggunakan SPSS. Diperoleh nilai rata-rata pre-test 44,79 sedangkan rata-rata post-test 73,74 . Sedangkan nilai sig.2-tailed adalah $0,017<5 \%$. Hasil pengabdian pada masyarakat ini menunjukkan bahwa: 1) pemberian pelatihan soal berbasis literasi numerasi ini memberikan pengaruh yang signifikan pada hasil belajar siswa. 2) pelaksanaan pelatihan soal berbasis literasi numerasi matematika terlaksana dengan baik dan dapat dinyatakan berhasil.
\end{abstract}

Kata kunci: literasi, numerasi, matematika, pelatihan

\section{Abstract}

This community service aims to: 1) provide knowledge for students related to numeration-based math literacy questions, 2) train students' skills in solving numerationbased math literacy questions. The method used is to provide training and mentoring students in solving problems based on numeration math literacy. Training is done virtually with google form and zoom applications. The data was obtained from pre-test and post-test results and then tested the difference between the two averages using SPSS. It averaged a pre-test score of 44.79 while the post-test average was 73.74. While the sig.2-tailed value is $0.017<5 \%$. The results of this community service show that: 1) the provision of numerationbased literacy-based training has a significant influence on students' learning outcomes. 2) the implementation of numeration-based math literacy training is done well and can be declared successful.

Key words: literacy, numeration, mathematics, training

\section{PENDAHULUAN}

Matematika merupakan salah satu cabang ilmu yang perkembangannya menjadi pusat perhatian banyak orang. Kemampuan siswa dalam menyelesaikan masalah matematika beserta aplikasinya dalam kehidupan sehari-hari dijadikan sabagai gambaran baik atau tidaknya kualitas pendidikan. Matematika yang penerapannya erat dengan berbagai macam konteks dalam kehidupan sehari-hari merupakan ilmu yang menggunakan angka dan simbol sebagai pendekatan keilmuannya.

Salah satu kemampuan yang identik dalam mempelajari matematika adalah literasi numerasi matematika. Lamada et al (2019) menyatakan bahwa perkembangan literasi menjadi penting untuk diperhatikan, 
karena literasi merupakan kemampuan awal yang harus dimiliki oleh setiap individu untuk menjalani kehidupan di masa depan. Ekowati et al (2019) menyatakan bahwa literasi numerasi diartikan sebagai kemampuan seseorang dalam menggunakan penalaran. Fokus dari kemampuan literasi numerasi ini adalah siswa dapat merumuskan, menerapkan, dan menginterpretasian matematika ke dalam berbagai konteks yang mencakup penalaran matematis dan menggunakan konsep matematika, prosedur, fakta, dan alat untuk menggambarkan, menjelaskan, dan memprediksi fenomena dalam kehidupan sehari-hari. Putra (2016) juga mengungkapkan bahwa literasi numerasi matematika sangat penting karena dapat membantu seseorang untuk memahami peran atau kegunaan matematika dalam kehidupan sehari-hari mereka.

Kemampuan literasi matematika membantu seseorang untuk memahami peran atau kegunaan matematika di dalam kehidupan sehari-hari (Puspitasari et al, 2015). Whardani (2011) juga mengungkapkan bahwa literasi matematika diartikan sebagai kemampuan seseorang untuk merumuskan, menerapkan dan menafsirkan matematika dalam berbagai konteks, termasuk kemampuan melakukan penalaran secara matematis dan menggunakan konsep, prosedur, dan fakta untuk menggambarkan dan menjelaskan. Terdapat lima kompetensi dalam pembelajaran matematika, yaitu: pemecahan masalah matematis (mathematical problem solving), komunikasi matematis (mathematical communication), penalaran matematis (mathematical reasoning), koneksi matematis (mathematical connection), dan representasi matematis (mathematical representation). Kemampuan yang mencakup kelima kompetensi tesebut adalah kemampuan literasi matematika (Fathani, 2016).

Literasi numerasi adalah pengetahuan dan kecakapan untuk :
1. Menggunakan berbagai macam angka dan simbol-simbol yang terkait dengan matematika dasar untuk memecahkan masalah praktis dalam berbagai konteks kehidupan sehari-hari.

2. Menganalisis informasi yaang ditampilkan dalam berbagai bentuk (grafik, tabel, bagan dan sebagainya) lalu menggunakan interpretasi hasil analisis tersebut untuk memprediksi dan mengambil keputusan. (Kemendikbud, 2017)

Sekolah Menengah Islam Terpadu Fitrah Insani Boarding School merupakan salah satu sekolah islam favorit di Bandar Lampung. SMAIT Fitrah Insani beralamatkan di jalan M.Ali no.1 Kelurahan Kedaung, Bandarlampung, Lampung. Sekolah ini juga menerapkan pembelajaran sesuai dengan kurikulum yang ditetapkan pemerintah. Dalam pelaksanaannya, pembelajaran matematika masih mengandalkan soal-soal yang langsung berupa simbol atau rumus-rumus, jarang ada soal yang berupa penerapan konteks dalam kehidupan sehari-hari. Umumnya siswa banyak yang mengeluh jika diberikan soal semacam ini, hal ini karena siswa masih kebingungan menghubungkan antara soal/permasalahan dalam kehidupan seharihari dengan simbol matematika dan penyelesaiannya. Fiangga et al (2019) mengungkapkan bahwa alasan utama yang menyebabkan siswa masih belum dapat menyelesaikan permasalahan berbasis literasi numerasi adalah guru yang belum membiasakan siswa dengan soal-soal berbasis literasi. Untuk itu, Mansur (2018) menyampaikan bahwa kemampuan literasi numerasi matematika siswa perlu dilatih dengan membiasakan memberikan latihan soal literasi numerasi matematika pada siswa.

\section{SOLUSI/TEKNOLOGI}

Solusi dari permasalahan kurangnya pengenalan soal-soal literasi numerasi pada siswa/i SMAIT Fitrah Insani adalah 
sehari-hari siswa. Hal ini terlihat selama proses pelatihan, siswa antusias mendengarkan materi dan aktif menjawab pertanyaan. Siswa juga saling berebut untuk menjawab soal yang diberikan. Oleh karenanya, berdasarkan hasil analisis data dan pelaksanaan pelatihan maka dapat dinyatakan bahwa kegiatan PkM ini terlaksana dengan baik, memberikan manfaat langsung bagi siswa dalam memahami dan menyelesaikan soal berbasis literasi numerasi. Secara keseluruhan, pelatihan soal berbasis literasi numerasi ini dapat dinyatakan berhasil dan terlaksana dengan baik.

Dalam PkM ini terdapat beberapa kendala diantaranya yaitu: 1) kegiatan dilaksanakan selama pandemi covid-19 sehingga tidak memungkinkan untuk melakukan pelatihan secara tatap muka langsung. 2) kegiatan PkM hanya memungkinkan dilaksanakan pada sebagian siswa kelas XI IPA atas izin guru dan perangkat sekolah lainnya. 3) tidak semua siswa menyelesaikan pengerjaan soal posttest.

\section{KESIMPULAN} ini yaitu:

Kesimpulan dari pelaksanaan PkM

1. pemberian pelatihan soal berbasis literasi numerasi ini memberikan pengaruh yang signifikan pada hasil belajar siswa.

2. pelaksanaan $\mathrm{PkM}$ pelatihan soal berbasis literasi numerasi matematika terlaksana dengan baik dan dapat dinyatakan berhasil.

\section{UCAPAN TERIMA KASIH}

Kegiatan PkM ini tidak luput dari dukungan dari banyak pihak. Oleh karenanya, ucapan terima kasih diberikan kepada: 1) Rektor Universitas Teknokrat Indonesia yang telah bersedia memberikan dana untuk kelancaran kegiatan pengabdian masyarakat ini, 2) LPPM Universitas Teknokrat Indonesia, 3) Kepala Sekolah, Guru matematika dan siswa/i SMAIT Fitrah
Insani yang telah membantu pelaksanaan kegiatan ini.

\section{PUSTAKA}

Ekowati, D.W., Astuti, Y.P., Utami, I.W.P., Mukhlishina, I., \& Suwandayani, B.I. Literasi Numerasi Di SD Muhammadiyah. ELSE (Elementary School Education Journal). Volume 3 Nomor 1 Februari 2019

Fathani, A.H. Pengembangan Literasi Matematika Sekolah Dalam Perspektif Multiple Intelligences. EduSains Volume 4 Nomor 2; 2016.

Fiangga, S., Amin, S.M., Khabibah, S., Ekawati, R. \& Prihartiwi, N.R. Penulisan Soal Literasi Numerasi bagi Guru SD di Kabupaten Ponorogo. Jurnal Anugerah, 1(1) (2019)

Lamada, M., Rahman, E.S. \& Herawati. Analisis Kemampuan Literasi Siswa SMK Negeri Di Kota Makassar. Jurnal Media Komunikasi Pendikan Teknologi dan Kejuruan. Vol.6 No.1 Februari 2019

Mansur, N. Melatih Literasi Matematika Siswa dengan Soal PISA. PRISMA.1. 2018.

Puspitasari, A., Setiawani, S. \& Nurcholif. Analisis Kemampuan Literasi Matematika Siswa Kelas X MIPA 5 SMA Negeri 1 Ambulu Berdasarkan Kemampuan Matematika. Artikel Ilmiah Mahasiswa, 2015.

Putra, Y.Y., Zulkardi \& Hartono, Y. Pengembangan Soal Matematika Model PISA Level 4, 5, 6 menggunakan Konteks Lampung. Kreano. Jurnal matematika kreatif dan inovatif. Vol.7, no.1. 2016

Wardhani, S., \& Rumiati. Instrumen Penilaian Hasil Belajar Matematika SMP: Belajar dari PISA dan TIMSS. Kemendikbud. 2011

RP3 (8): 1-11 